\title{
BOLEHKAH JENIS KELAMIN DALAM FORMULIR DONOR?
}

\author{
Tomy Michael \\ Fakultas Hukum Universitas 17 Agustus 1945 Surabaya \\ tomy@untag-sby.ac.id
}

\section{Abstract}

This research discussed about gender in the donor form at Transfusi Darah Kota Surabaya (UTDKS) Unit as the form attaches sex in the time of donation. Prior to further discussion about the gender flow, the legal justice must be understood from the beginning to facilitate the study of this research. The method used was juridical normative using primary and secondary legal materials. Besides, the formulation of the sex in UTDKS donor form was legally appropriate because the laws and regulations provide such an order. The sex that was then followed by the choice either male or female tended to check the health data of donor who was still beginning or had done it in advance.

Keywords: Donor, Form, Gender

\section{Abstrak}

Secara khusus, penelitian ini akan membahas jenis kelamin dalam formulir donor di Unit Transfusi Darah Kota Surabaya (UTDKS) karena dalam formulir ini mencantumkan jenis kelamin pada saat melakukan donor. Sebelum memasuki alur jenis kelamin maka keadilan hukum harus dipahami sejak awal untuk mempermudah telaah penelitian ini. Metode penelitian yang digunakan adalah yuridis normatif dengan menggunakan bahan hukum primer dan sekunder. Rumusan jenis kelamin dalam formulir donor UTDKS adalah tepat secara hukum karena peraturan perundang-undangan memberikan perintah demikian. Jenis kelamin yang kemudian diikuti dengan pilihan laki-laki atau perempuan ini cenderung pada pengecekan data kesehatan bagi pendono yang akan baru atau telah melakukannya.

Kata Kunci: Donor, Formulir, Jenis Kelamin

\section{PENDAHULUAN}

Dunia hukum selalu mengandaikan kehidupan bermasyarakat yang memiliki teleologi, dalam hal ini keadilan hukum adalah puncaknya. Namun dalam praktiknya, keadilan hukum adalah hal-hal yang sulit tercapai dikarenakan sangat sulitnya untuk mendefinisikan makna keadilan hukum. Dalam beberapa perspektif, keadilan hukum akan dibenturkan dengan ketidakadilan dan keraguan, akan memasuki medan wilayah non sistematik atau anti sistematik bahkan hampir bersifat aphoristic karena membicarakan keadilan, ketidakadilan, keraguan kita berdiri pada wilayah yang labil, goyah atau cair. Oleh karena itulah, keadilan (hukum) dianggap plural dan plastik (Indarti, 2008: 33). Ada juga yang mengatakan bahwa keadilan hukum tertinggi tercermin dalam konstitusi karena disana mencakup hak kebebasan secara personal ataupun pengaturan hak-hak lainnya (Dicey, 1915: 124). 
Secara khusus, penelitian ini akan membahas jenis kelamin dalam formulir donor di Unit Transfusi Darah Kota Surabaya (UTDKS) karena dalam formulir ini mencantumkan jenis kelamin pada saat melakukan donor. Sebelum memasuki alur jenis kelamin maka keadilan hukum harus dipahami sejak awal untuk mempermudah telaah penelitian ini.

Di Indonesia dalam Pasal 28H ayat (1) Undang-Undang Dasar Negara Republik Indonesia Tahun 1945 (UUD NRI 1945) dijelaskan bahwa siapapun memiliki hak terkait hidup secara sejahtera lahir dan batin, memiliki tempat tinggal, dan memperoleh lingkungan hidup yang baik dan sehat serta memiliki hak dalam pelayanan kesehatan. Ketika setiap orang dimaknai sebagai orang maka orang tersebut adalah subjek hukum tanpa membeda-bedakan identitasnya. Dalam keilmuan, gender dikenalkan awal mula oleh peminat ilmu sosial yang digunakan untuk menjelaskan perbedaan perempuan dan laki-laki yang bersifat bawaan sebagai ciptaan Tuhan dan yang bersifat bentukan budaya yang dipelajari dan disosialisasikan sejak kecil. Adanya pembedaan ini sangat penting, karena selama ini sering sekali mencampur adukan ciri-ciri manusia yang bersifat kodrati dan yang bersifat bukan kodrati (gender). Perbedaan peran gender ini sangat membantu kita untuk memikirkan kembali tentang pembagian peran yang selama ini dianggap telah melekat pada manusia perempuan dan laki-laki untuk membangun gambaran relasi gender yang dinamis dan tepat serta cocok dengan kenyataan yang ada dalam masyarakat. Perbedaan konsep gender secara sosial telah melahirkan perbedaan peran perempuan dan laki-laki dalam masyarakatnya. Secara umum adanya gender telah melahirkan perbedaan peran, tanggung jawab, fungsi dan bahkan ruang tempat dimana manusia beraktivitas. Sedemikian rupanya perbedaan gender menurut Supardin (2013) ini melekat pada cara pandang kita, sehingga kita sering lupa seakan-akan hal itu merupakan sesuatu yang permanen dan abadi sebagaimana permanen dan abadinya ciri biologis yang dimiliki oleh perempuan dan laki-laki (Puspitawati, 2012). Dari pemahaman demikian, gender lebih bersifat bukan kodrati. Dalam perspektif demikian, siapapun yang ingin melakukan kegiatan kemanusiaan harus diperlakukan secara adil.

Di dalam formulir donor UTDKS ketika ada penegasan jenis kelamin maka tidak sesuai dengan hakikat kemanusiaan . Pembahasan secara lengkap akan dibahas dalam sub bab pembahasan.

Adanya pengungkapan mengapa penelitian ini dilakukan seperti yang tertulis dalam sub bab latar belakang, maka terdapat rumusan masalah yang dapat diambil. Rumusan masalah ini hanya satu yang berupa pernyataan yaitu jenis kelamin dalam formulir donor.

\section{METODE PENELITIAN}

Metode penelitian merupakan prosedur atau cara penelitian di dalam mengumpulkanxdan menganalisis bahan hukum. Jenis penelitian yang digunakan dalam penelitian ini aadalah penelitian hukum normatif yakni penelitian hukum untuk menemukan aturan hukum, menyelaraskan prinsip-prinsip hukum, maupun doktrin-doktrin hukum guna menjawab isu hukum yang dihadapi. Penelitian hukum 
normatif dilakukan untuk mencari pemecahan masalah atau isu hukum yang ada. Hasil dari penelitian ini adalah memberikan preskripsi tentang rumusan masalah yang diajukan (Evi, 2019).

\section{HASIL PENELITIAN DAN PEMBAHASAN Gender Dalam Keindonesiaan}

Istilah kesetaraan dalam kajian isu gender lebih sering digunakan dan disukai, karena makna kesetaraan laki-laki dan perempuan lebih menunjukkan pada pembagian tugas yang seimbang dan adil dari laki-laki dan perempuan. Untuk lebih memberikan pemahaman akan makna kesetaraan antara laki-laki dan perempuan, yang dalam hal ini sering juga disebut dengan istilah kesetaraan gender, maka menurut Djohani (1996: 7), gender adalah "pembagian peran, kedudukan dalam tugas antara laki-laki dan perempuan yang ditetapkan oleh masyarakat berdasarkan sifat perempuan dan laki-laki yang dianggap pantas menurut norma-norma, adat istiadat, kepercayaan atau kebiasaan masyarakat".

Ketika pembagian gender dinormakan maka akan muncul berbagai pengaturan tentangnya, antara lain:

a. Pasal 7 Peraturan Daerah Kota Surabaya Nomor 2 Tahun 2019 tentang Kawasan Tanpa Rokok dijelaskan bahwa "Setiap orang dilarang menjual rokok kepada perempuan hamil".

b. Pasal 81 Undang-Undang Republik Indonesia Nomor 13 Tahun 2003 tentang Ketenagakerjaan dijelaskan bahwa "Pekerja/buruh perempuan yang dalam masa haid merasakan sakit dan memberitahukan kepada pengusaha, tidak wajib bekerja pada hari pertama dan kedua pada waktu haid.

Dalam pemahaman demikian, undang-undang bisa bersikap adil terhadap satu subjek hukum namun tidak terhadap subjek hukum lainnya dan bersikap adil dengan mengesampingkan subjek hukum lainnya (Qs. Al-A'raf: 27). Gender dalam keindonesiaan memegang peranan penting terutama dalam norma hukum karena masih diakuinya hukum adat dan kebiasaan sebagai norma hukum.

\section{Keadilan Hukum Dalam Formulir Donor UTDKS}

Mengacu pada Pasal 2 Undang-Undang Republik Indonesia Nomor 36 Tahun 2009 tentang Kesehatan (UU No. 36-2009) dijelaskan bahwa "Pembangunan kesehatan diselenggarakan dengan berasaskan perikemanusiaan, keseimbangan, manfaat, pelindungan, penghormatan terhadap hak dan kewajiban, keadilan, gender dan nondiskriminatif dan norma-norma agama". Pemahaman demikian secara jelas bahwa kesehatan tetap mengutamakan kemanusiaan dimana tidak ada perilaku diskriminatif. Kemudian Pasal 86 hingga Pasal 92 UU No. 36-2009 terkait pelayanan darah yang pengaturannya dapat dibagi menjadi:

a. Pelayanan darah berkait erat dengan tujuan kemanusiaan dan tidak bersifat komersial.

b. Pelayanan transfusi darah untuk tujuan kesehatan. 
c. Adanya bentuk pertanggungjawaban yang diberikan pemerintah kepada masyarakat atas pelayanan yang aman, yang mudah diakses dan sesuai kebutuhan masyarakat.

Kelanjutan pasal ini tertuang dalam Peraturan Pemerintah Republik Indonesia Nomor 7 Tahun 2011 tentang Pelayanan Darah (PP No. 7-2011). Dalam penjelasannya tertulis asas gender dan nondiskriminatif berarti bahwa pelayanan darah tidak membedakan perlakuan terhadap perempuan dan laki-laki; serta asas norma agama berarti pelayanan darah harus memperhatikan dan menghormati serta tidak membedakan agama yang dianut pendonor darah, pemberi pelayanan transfusi darah dan penerima pelayanan transfusi darah. Pelayanan darah dalam arti luas mencakup kepentingan publik yang mendasar dan menjangkau kebutuhan jutaan manusia. Oleh karena itu kebijakan pengaturan dalam Peraturan Pemerintah ini harus dilaksanakan dengan tetap berlandaskan pada asas perikemanusiaan, keseimbangan, manfaat, pelindungan, penghormatan terhadap hak dan kewajiban, keadilan, gender dan nondiskriminatif serta norma agama. Tentu saja kemanusiaan adalah hal utama tanpa membedakan jenis kelamin dalam proses transfuse.

Setelah dari PP No. 7-2011 maka pengaturan spesifiknya pada Peraturan Menteri Kesehatan Republik Indonesia Nomor 91 Tahun 2015 tentang Standar Pelayanan Transfusi Darah (Permenkeseh No. 91-205 khususnya dalam Bab III Pelayanan Transfusi Dara Di Unit Transfusi Darah dimana "jenis kelamin" adalah bagian dari tahap registrasi. Secara lengkap terdiri dari:

a. Identitas (KTP/Surat Ijin Mengemudi/nomor paspor, untuk orang asing)

b. Nomor kartu donor (donor terdahulu)

c. Nama lengkap meliputi nama pertama, tengah dan akhir

d. Alamat rumah termasuk kelurahan, kecamatan dan kota

e. Alamat kantor

f. Nomor telepon

g. Jenis kelamin

h. Tanggal lahir

i. Tempat lahir

j. Pekerjaan

k. Tanggal, waktu dan tempat penyumbangan darah

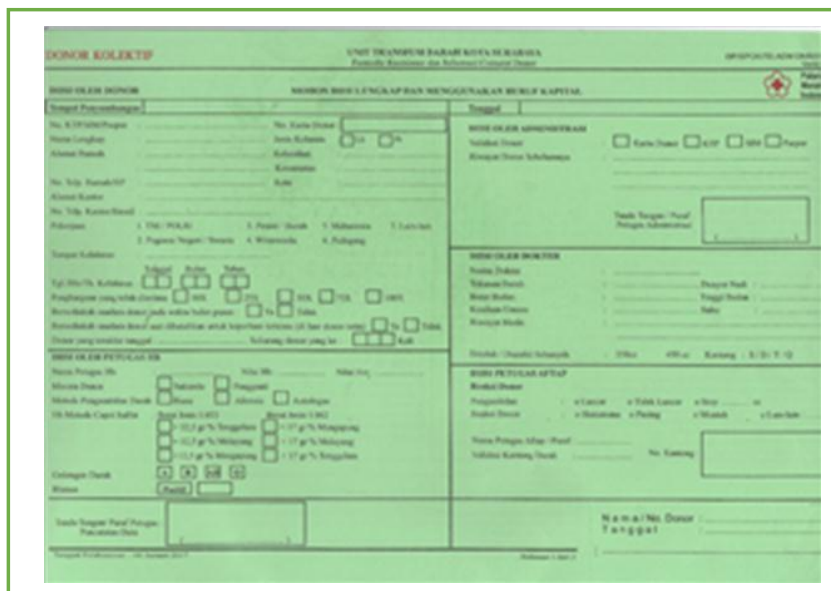

Gambar 1. Formulir Donor Kolektif

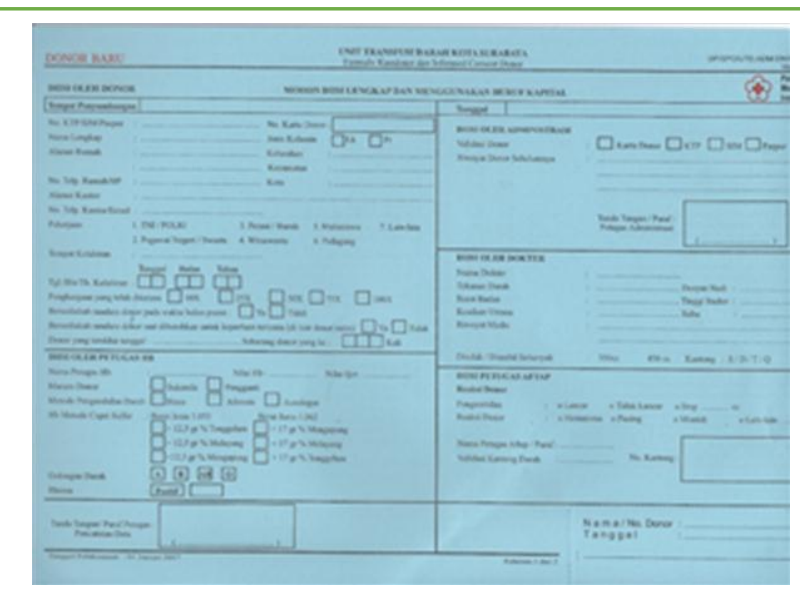

Gambar 2. Formulir Donor Baru 


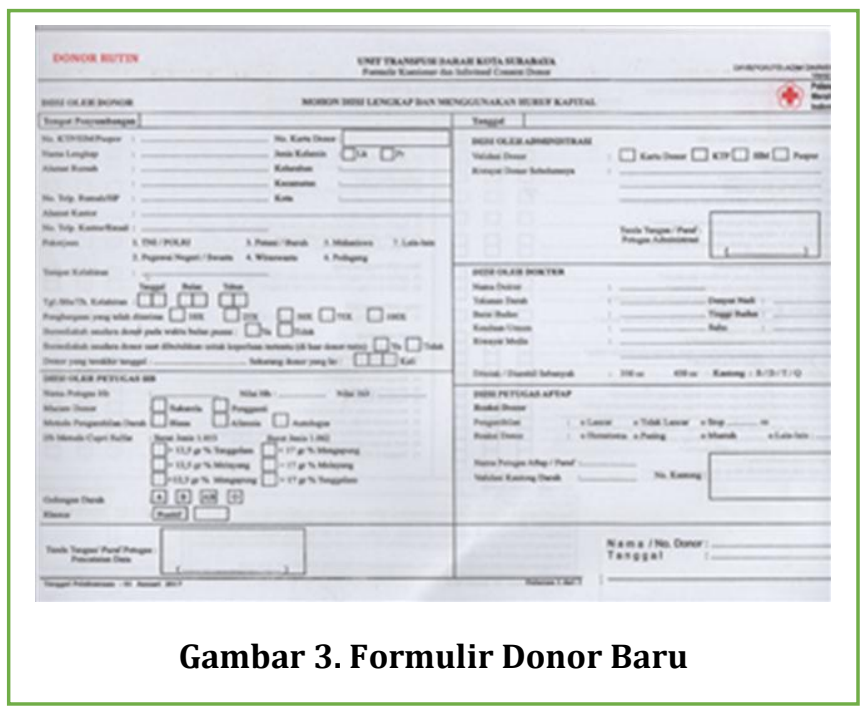

Tabel 1. Penjelasan Terkait Laki-laki dan Perempuan

\begin{tabular}{|l|l|l|}
\hline \multicolumn{1}{|c|}{ Komponen } & \multicolumn{1}{|c|}{ Kriteria } & \multicolumn{1}{c|}{ Persyaratan } \\
\hline Penyumbangan & Interval waktu sejak & - Laki-Laki : 2 bulan \\
darah lengkap & Penyumbangan terakhir & - Perempuan : 2 bulan \\
(Whole Blood) & & $\begin{array}{l}\text { - 48 jam jika Penyumbangan terakhir adalah } \\
\text { prosedur plasmapheresis atau } \\
\end{array}$ \\
& & $\begin{array}{l}\text { plateletpheresis (dan dalam jumlah maksimal } \\
\text { penyumbangan darahblengkap per tahun) }\end{array}$ \\
\hline & Frekuensi pengambilan & - Laki-Laki 6 penyumbangan pertahun \\
& & - Perempuan 4 penyumbangan pertahun \\
\hline
\end{tabular}

\section{PENUTUP}

Di dalam bagian ini, kesimpulan yang dihasilkan adalah:

1. Rumusan jenis kelamin dalam formulir donor UTDKS adalah tepat secara hukum karena peraturan perundang-undangan memberikan perintah demikian. Jenis kelamin yang kemudian diikuti dengan pilihan laki-laki atau perempuan ini cenderung pada pengecekan data kesehatan bagi pendonor yang akan baru atau telah melakukannya.

2. Rumusan jenis kelamin dalam formulir donor UTDKS menjadi tidak tepat karena menimbulkan ketidakadilan dalam kehidupan bermasyarakat. Artinya data tersebut tidak perlu diisi setiap pendonor karena data digital harus dikelola dengan baik.

Sebagai masukan yang dapat ditulis yaitu kesehatan secara fisik seperti keadaan pada saat donor adalah hal penting daripada pencantuman untuk mengisi jenis kelamin. Dengan adanya pencantuman maka asas perikemanusiaan tidak terlaksana dengan baik. 


\section{DAFTAR PUSTAKA}

A. V. Dicey, (1915). Introduction to the Study of The Law of the Constitution, London: Macmillan,.

Cahya Edi Setyawan (2017), Pemikiran Islam Pemikiran Kesetaraan Gender Dan Feminisme Amina Wadud Tentang Eksistensi Wanita Dalam Kajian Hukum Keluarga. Zawiyah, Jurnal Pemikiran Islam Vol. 3 No. 1, Juli 2017, Pascasarjana IAIN Kendari.

Catharine A. MacKinnont, (1991). Reflections on Sex Equality Under Law. The Yale Law Journal, Vol. 100, No. 5, Centennial Issue (Mar., 1991), pp. 1281-1328, The Yale Law Journal Company, Inc.

Djohani, Rianingsih, (1996). Dimensi Gender dalam Pengembangan Program Secara Partisipatif. Bandung: Driya Media Bandung.

Eckert, Penelope, Mc Connell-Ginet, Languange and Gender, New York: Cambridge Universty Press.

Erny Indarti, (2008). Demokrasi dan Kekerasan: Sebuah Tinjauan Filsafat Hukum. Aequitas Jurnal, Jurnal Fakultas Hukum Universitas Katolik Widya Mandira Kupang, Fakultas Hukum Universitas Katolik Widya Mandira, Vol 2 (1), 2008.

Evi Kongres, (2019). Peran Shipbroker Dalam Sale And Purchase Of Second Hand Vessel. DiH: Jurnal Ilmu Hukum Volume 15 Nomor 2 Agustus 2019 - Januari 2020, Program Studi Doktor Ilmu Hukum Fakultas Hukum Universitas 17 Agustus 1945 Surabaya.

Herien Puspitawati, (2012). Konsep, Teori Dan Analisis Gender. Bogor: PT. IPB Press.

Lisa M. Cookingham, MD, Ginny L, Ryan MD, MA, (2015). The Impact of Social Media on the Sexual and Social Wellness of Adolescents. Journal of Pediatric and Adolescent Gynecology February 2015, Department of Obstetrics \& Gynecology, University of Iowa Carver College of Medicine, Iowa City, IA.

Supardin, (2013). Kajian Gender Perspektif Hadis Nabi. AL-FIKR Q Volume 4817 Nomor 1 Tahun 2013. Fakultas Ushuluddin dan Filsafat UIN Alauddin Makassar Samata, Gowa.

Syahrul Amar, (2017). Perjuangan Gender Dalam Kajian Sejarah Wanita Indonesia Pada Abad XIX. Fajar Historia, Volume 1 Nomor 2, Desember 2017, hal. 105-119, Program Studi Pendidikan Sejarah FKIP Universitas Hamzanwadi Volume 1 Nomor 2, Desember 2017. 
Tomy Michael, (2015). Kritik Terhadap Kata "Agama" Pada Kuesioner Riwayat Kesehatan \& Pernyataan Donor" Di Palang Merah Indonesia Kota Surabaya Unit Donor Darah. DiH: Jurnal Ilmu Hukum Pebruari 2015, Vol. 11, No. 21, Hal. 33 - 38, Program Studi Doktor Ilmu Hukum Fakultas Hukum Universitas 17 Agustus 1945 Surabaya. 